\title{
DETECTING THE EFFECT OF IRRIGATION WATER QUALITIES ON THE HETEROGENEITY OF CLOVER BIOMASS USING GEOGRAPHIC INFORMATION SYSTEMS (GIS) AND PASSIVE REFLECTANCE SENSOR
}

\author{
Ibrahim, M. M. ${ }^{(1)}$ and S. Elsayed ${ }^{(2)}$
}

\begin{abstract}
Heterogeneous biomasses stands of cultivars require maximize the efficiency of crop inputs within small areas of the farm field. However, its determination via classical measurements to cover full area of site is tedious and time-consuming. The precision agriculture technologies based on the passive reflectance sensor and GIS tools have the potential for fast and non-destructive measurements for different parameters. In the present study, the performance of GIS maps based on two spectral reflectance indices $\left(R_{780} / R_{740}\right.$ and $\left.R_{780} / R_{700}\right)$ for assessing the heterogeneity in vegetation Clover biomass under fresh, drainage and mixed water was tested. The results showed that there were significant variations in spectral index $\left(R_{780} / R_{740}\right)$ values, spectral index $\left(R_{780} / R_{700}\right)$ values and Clover biomass weights under fresh water, drainage water and mixed water. There were a more pronounced strong negative relationships between spectral index $\left(R_{780} / R_{740}\right)$ and Clover biomass and the coefficients of determination varied between (0.92*** to 0.93***) under three water qualities. As well as there were a more pronounced strong positive relationships between spectral index $\left(R_{780} / R_{700}\right)$ and Clover biomass and the coefficients of determination varied between $\left(0.88^{* *}\right.$ to $\left.0.96^{* *}\right)$ under three water qualities. In conclusion, the GIS maps based on two spectral reflectance indices $\left(R_{780} / R_{740}\right.$ and $\left.R_{780} / R_{700}\right)$ were useful to describe the heterogeneity in vegetation Clover biomass under three water qualities.
\end{abstract}

Key words: precision agriculture, GIS, spectral indices, site specific management, water quality

\footnotetext{
${ }^{1}$ Assistant Prof. of Agric. Eng. Dept., Faculty of Agric., Al-Mansoura University ${ }^{2}$ Assistant Prof. of Agric. Eng. Evaluation of Natural Resources Department, Environmental Studies and Research Institute, Sadat City University.
} 


\section{INTRODUCTION}

The increasing of soil and groundwater pollution from farming activities has not a desirable benefit to the farmer and to society. Soil conditions such as water and nutrient supply, exposition and inclination may vary on heterogeneous agriculture field sites leading to differences in plant growth and production (Auerswald et al., 1997). For economical target and ecological reasons temporally and spatially optimized these application is required by using precision agriculture tools. Precision agriculture or farming is an integration of many technologies such as remote Sensing, geographic positioning system (GPS) and geographic information system (GIS). The target of precision farming is to gather and analyze information about the variability of soil and crop conditions in order to maximize the efficiency of crop inputs within small areas of the farm field. To meet this efficiency target the variability within the field must be controllable (Mistele and Schmidhalter. 2008). The growing competition of Nile fresh water available from population growth and increasing consumption of fresh water in the agricultural sector which consumes about $75 \%$ (El-Hendawy et al., 2015) has led to utilization of low quality water in irrigation proposals (Allam et al., 2013). Some regions of Nile Delta suffer from fresh water shortage for irrigation proposal. For that, the farmers are forced to use the low water quality such as sewage water and drainage water for irrigation process. Longterm irrigation with low water quality could be restricted soil function and nutrients uptake which leads to directly change in soil and plant homogenies by change physical and hydraulic properties (Yadar et al., 2002). The precision agriculture technologies have been used as very useful tools monitor crops throughout their growing period to support decisions for good agricultural practices by taking advantages of numerous available technologies, such as electromagnetic induction, geographic positioning system (GPS), reflectance sensing and laser sensor (Thoren and Schmidhalter 2009; Elsayed et al. 2015; Rischbeck et al., 2016). To the best of our knowledge, there is very little information available about the study of the ability of GIS Maps based on spectral reflectance indices for assessing the vegetation Clover biomass under mixed, drainage and fresh water. 
Geographic information systems are computer hardware and software that use feature attributes and location data on produce maps and have been used in this study with spectral reflectance data. An important function of agriculture GIS is to store layers of information such as remotely sensed data, yield or biomass and so on. Geographically referenced data can be displayed in GIS adding a visual perspective for interpretation (Heil and Schmidhalter. 2016). There are many available interpolation methods such as Inverse Distance Weighted, Natural Neighbour, Spline, Kriging and Trend (Brus, et al., 1996). In our study; the used interpolation method is Inverse Distance Weighted "IDW". The Inverse Distance Weighting interpolator assumes that each input point has a local influence that diminishes with distance. It weights the points closer to the processing cell greater than those do further away.

For fast measurement to detect the heterogeneity in vegetation of Clover, the passive reflectance sensor coupled with GPS unit was used in this study. Passive sensor systems depend on sunlight as a source of light. Passive reflectance sensor has been tested to assessment biomass, nitrogen status and yield under different nitrogen fertilizer and irrigation regimes conditions (El-Shikha et al., 2007). Several spectral regions are useful for the detection plant traits. In one of the earliest reports, Wolley (1971) identified the visible spectra (VIS; $400-700 \mathrm{~nm}$ ) as being suitable for this purpose. Reflectance changes in the near infrared region (NIR; $700-1300 \mathrm{~nm}$ ) can also be used for the detection of biomass and water in biological samples because the NIR penetrates more deeply into the measured structures than middle infrared (MIR; 1300-2500 nm).

The purpose of this work was to study the performance of GIS Maps based on two spectral reflectance indices $\left(R_{780} / R_{700}\right.$ and $\left.R_{780} / R_{740}\right)$ for assessing the heterogeneity in vegetation Clover biomass under mixed, drainage and fresh water.

\section{MATERIALS AND METHODS}

The present study was conducted at Manyt Elnasr, Dakahlia Governorate, Egypt (Latitude: N 31 5' .20", Longitude: E 31 41' 20") during 2015 2016 (Fig. 1). Some fields in this region are seriously lacking from Nile fresh water. Since several years, the farmers in this region use mixed water (sewage water mixed with drainage water) as well as using the 
drainage water for irrigation. In this study, three sites from this region (first site; irrigated with fresh water (FW), second site; irrigated with drainage water (DW) and third site; irrigated with mixed water (MW)) were selected. Clover seed were sown on 15 October 2015 in clay loam. Fertilizer $\left(50 \mathrm{~kg} \cdot \mathrm{fed}^{-1}\right.$ in the form of ammonium nitrate $(33.5 \% \mathrm{~N})$ and $100 \mathrm{~kg} \cdot \mathrm{fed}^{-1}$ in the form of Superphosphate (15.5\% P2O5) was applied uniformly at the early to full growing vegetative stages across the experiment as recommended for Clover production in this area. The soil of the experimental site has water field capacity of $43 \%$, welting point of $22.4 \%$ and bulk density of $1.31 \mathrm{~g} \cdot \mathrm{cm}^{-3}$. The surface irrigation is applied about 9 irrigations for all sites based on Clover water-use. The surface irrigation is applied about 9 irrigations for all sites based on Clover wateruse. Irrigation water applied used fresh water with an EC $=358 \mathrm{ppm}$, $\mathrm{TDS}=232 \mathrm{mg} / \mathrm{L}$ and $\mathrm{pH}=7.45$ ).

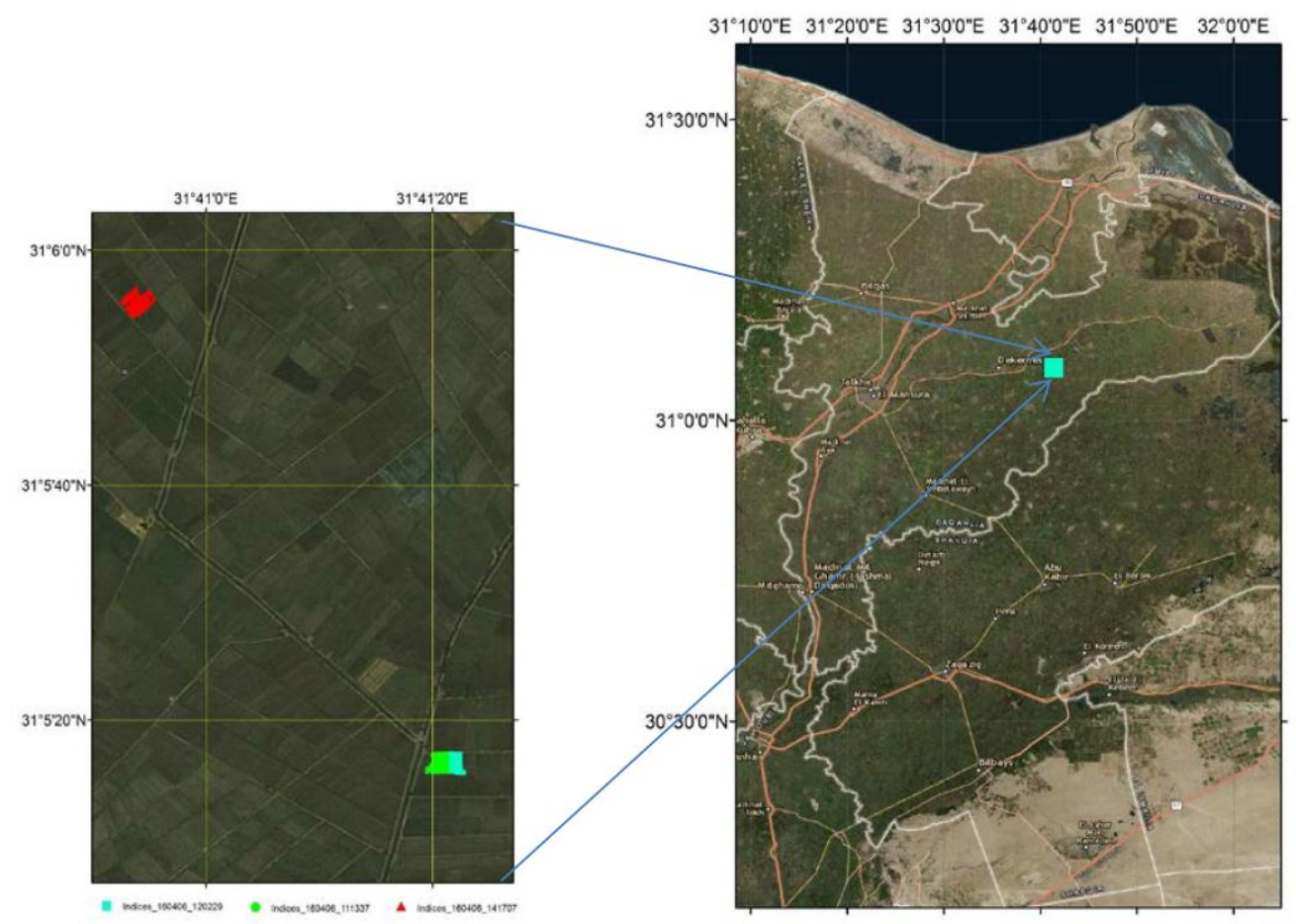

Figure 1. Map of the studied area and region 
For drainage water irrigation water applied with an EC $=960 \mathrm{ppm}, \mathrm{TDS}=$ $622 \mathrm{mg} / \mathrm{L}$ and $\mathrm{pH}=7.20$ ). Irrigation water applied used mixed water with an $\mathrm{EC}=1152 \mathrm{ppm}$, TDS $=747 \mathrm{mg} / \mathrm{L}$ and $\mathrm{pH}=7.62$ ). Soil analysis used fresh water with an $\mathrm{EC}=534 \mathrm{ppm}$, TDS $=346 \mathrm{mg} / \mathrm{L}$ and $\mathrm{pH}=7.65$ ). For drainage water Soil analysis with an EC $=1060 \mathrm{ppm}$, TDS $=688 \mathrm{mg} / \mathrm{L}$ and $\mathrm{pH}=7.65$ ). Soil analysis used mixed water with an $\mathrm{EC}=1390 \mathrm{ppm}$, $\mathrm{TDS}=902 \mathrm{mg} / \mathrm{L}$ and $\mathrm{pH}=8.04$ ).

\section{Description of passive reflectance sensor and spectral reflectance measurements with GPS unit}

A passive bi-directional reflectance sensor (tec5, Oberursel, Germany) measuring wavelengths between $302-1148 \mathrm{~nm}$, with a bandwidth of 2 $\mathrm{nm}$ and connected to a portable computer and geographical positioning system (GPS), was used. The FieldSpec sensor consists of two units. One unit was linked with a diffuser and measured the light radiation as a reference signal. The second unit measured the canopy reflectance with a fiber optic (Elsayed et al. 2015; Rischbeck et al. 2016) with an aperture of $12^{\circ}$ and a field of view of $0.2 \mathrm{~m}^{2}$ from one meter of height. The aperture of an optical system is the opening that determines the cone angle of a bundle of rays that enter the optics. The sensor outputs were co-recorded along with the GPS coordinates when collecting information in the field each site. The actual sensor output was co-referenced and recorded for each point. The canopy reflectance was calculated with the readings from the spectrometer unit and corrected with a calibration factor obtained from a reference grey standard. Spectral measurements were mostly taken on sunny days at nadir direction approximately $1.5 \mathrm{~m}$ above the canopy with width $1 \mathrm{~m}$ between two rows. Readings were taken during fifth harvest growth stage of Clover. In this study, we calculated and tested both known and novel indices. The selected two indices generally presented more stable and strong relationships with Clover biomass. First spectral index is ratio of near infrared to near infrared (NIR/NIR $\left.=R_{780} / R_{740}\right)$ and second spectral index is ratio of near infrared to red (NIR/R= $\mathrm{R}_{780} / \mathrm{R}_{700}$ ).

The Global Positioning System (GPS) is a space based navigation system that provides location and time information in all weather conditions, anywhere on or near the earth where there is an unobstructed line of sight 
to four or more GPS satellites. During the several filed trip. A lot of data can be provided by this device such as date, time and location measurement (degree and meters), UTM zone and the angle of inclination of the solar beam. The correction signal and the number of satellites that permitted to scan the measuring points and the speed of movement the device with the movement angle are shown in table (1). The temperature of atmosphere with spectrum and the number of plots corrects, in addition, the temperature degree, the global radiation green and other data are shown in table (1).

\section{ArcGIS Spatial Analyst}

The ArcGIS Spatial Analyst 10.2.1 extension provides tools for spatial data analysis that apply statistical theory and techniques to the modelling for spatially referenced data. The data of two spectral indices (NIR/NIR= $\left.\mathrm{R}_{780} / \mathrm{R}_{740}\right)$ or $\left(\mathrm{NIR} / \mathrm{R}=\mathrm{R}_{780} / \mathrm{R}_{700}\right)$ are used to drive the intervening values using the interpolation tools in ArcGIS Spatial Analysis (Figs. 4 and 5). The interpolation is the process of using points with known values or sample points to estimate values at other unknown points. It can be used to predict unknown values for any geographic point data, such as elevation, rainfall, chemical concentrations, noise levels, and so on. In our study, the used interpolation method is Inverse Distance Weighting "IDW" to produce the final maps (Figs. 4 and 5). The Inverse Distance Weighting interpolator assumes that each input point has a local influence that diminishes with distance. It weights the points closer to the processing cell greater than those do further away. A specified number of points or all points within a specified radius can be used to determine the output value of each location. Use of this method assumes the variable being mapped decreases in influence with distance from its sampled location IDW interpolation explicitly implements the assumption that things that are close to one another are more alike than those that are farther apart. To predict a value for any unmeasured location, IDW will use the measured values surrounding the prediction location. Those 
measured values closest to the prediction location will have more influence on the predicted value than those farther away.

Table (1) Characteristics of Passive bi-directional reflectance sensor with

\section{GPS unit}

\begin{tabular}{|c|c|c|c|c|c|c|c|c|c|c|}
\hline Date & Time & \multicolumn{2}{|c|}{ Long (X) } & \multicolumn{2}{|c|}{ Lat. (Y) } & $\mathrm{X}$ & $\mathrm{Y}$ & UTM & Byte & Altitude \\
\hline 160406 & 111458.38 & 31.688 & 833 & \multicolumn{2}{|c|}{$31.08790467 \mid$} & $0083.01:$ & 374937.89 & 36 & 0 & -16.4 \\
\hline HDOP & Satellites & $\begin{array}{l}\text { orrection } \\
\text { signal }\end{array}$ & \multicolumn{2}{|c|}{ iPS-Time } & $\begin{array}{c}\text { Azimuth } \\
\text { motion }\end{array}$ & Speed/s & \multicolumn{2}{|c|}{ /s Azimuth sun } & Zenith sun & $\begin{array}{l}\text { Temp. } \\
\text { Spec }\end{array}$ \\
\hline 1.1 & 9 & 2 & \multicolumn{2}{|c|}{20943.2} & 186.4 & 0.6 & \multicolumn{2}{|l|}{154.1} & 63.1 & 32.2 \\
\hline GPS_invalid & $\begin{array}{c}\text { Average_ } \\
\text { Spectra }\end{array}$ & Plot & $\begin{array}{l}\text { Point_ } \\
\text { no. }\end{array}$ & \multicolumn{2}{|c|}{$-\mid \begin{array}{c}\text { Measurement } \\
\text { no. }\end{array}$} & $\begin{array}{l}\text { egration } \\
\text { Time }\end{array}$ & \multicolumn{2}{|c|}{ 1_Dark_current } & $\begin{array}{c}\text { t } \\
\begin{array}{c}\text { Temp_corr } \\
\text { glob }\end{array}\end{array}$ & $\begin{array}{c}\text { Temp_corr } \\
\text { _can }\end{array}$ \\
\hline 1 & 1 & 1 & 4 & & 8 & 120 & 1 & & 10.551 & 8.762 \\
\hline $\begin{array}{c}\text { Global_radiation } \\
\text { green }\end{array}$ & \multicolumn{2}{|c|}{ NIR/NIR } & \multicolumn{2}{|c|}{ NIR/red } & \multicolumn{2}{|c|}{ X_tilt } & Y_tilt & \multicolumn{2}{|c|}{ Prog_version } & 302 \\
\hline 170.96 & \multicolumn{2}{|c|}{0.928} & \multicolumn{2}{|c|}{15.274} & \multicolumn{2}{|c|}{-0.04533} & -0.83333 & \multicolumn{2}{|r|}{ '1.0.0.0 } & 7.672 \\
\hline
\end{tabular}

\section{Destructively measured parameter}

After GIS maps of the data of two spectral indices were produced, the vegetation Clover biomass samples were determined in three fields experimental under fresh, drainage and mixed water. Ten positions from each field were selected and the biomass of one meter square was cut from each position to test and calibrate the performance of two spectral indices of passive reflectance sensor for detect the heterogeneity in vegetation of Clover under different water quality.

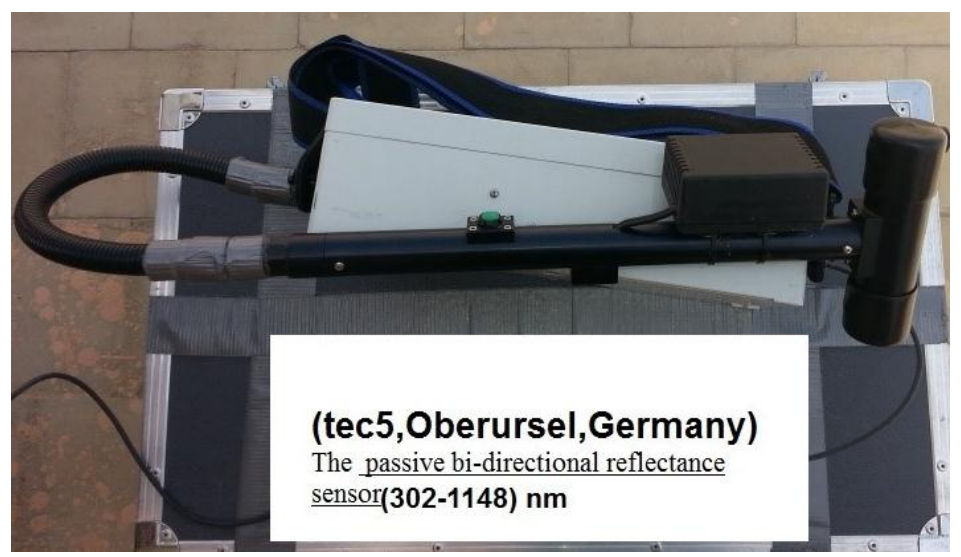

Figure 2. A passive bi-directional reflectance sensor measuring wavelengths between $302-1148 \mathrm{~nm}$ coupled with GPS unit 


\section{RESULTS AND DISCUSSION}

\section{Influence of three water qualities on the spectral index (NIR/NIR), spectral index (NIR/R) and biomass of Clover}

There were variations in spectral index $\left(\mathrm{R}_{780} / \mathrm{R}_{740}\right)$ values, spectral index $\left(\mathrm{R}_{780} / \mathrm{R}_{700}\right)$ values and Clover biomass weights under fresh water, drainage water and mixed water (Table 2). The highest value of spectral index $\left(R_{780} / R_{740}\right)$ and Clover biomass were recorded under fresh water treatment. The highest value of spectral index $\left(\mathrm{R}_{780} / \mathrm{R}_{700}\right)$ was recorded under drainage water treatment. There was no significant difference between Clover biomass under fresh water treatment and drainage water treatment as well as no significant difference in Clover biomass under drainage water treatment and mixed water treatment. These results are in agreement with Juwarker et al. (1991), who found that the continuous use of untreated water for irrigation significantly reduced the yield of wheat, cotton and paddy. However, the use of primary treated sewage proved to be beneficial for both wheat and cotton.

Table 2. Average spectral index $\left(\mathbf{R}_{780} / \mathbf{R}_{740}\right)$, spectral index $\left(\mathbf{R}_{780} / \mathbf{R}_{700}\right)$ and Clover biomass under fresh water (FW), drainage water (DW) and mixed water (MW). Values with the same letter are not significantly different $(P \geq$ 0.05) among treatments according to Duncan's test. SD indicates standard deviation.

\begin{tabular}{ccccccc}
\hline $\begin{array}{c}\text { Water } \\
\text { quality }\end{array}$ & $\mathbf{R}_{\mathbf{7 8 0}} / \mathbf{R}_{\mathbf{7 4 0}}$ & $\mathbf{S D}$ & $\mathbf{R}_{\mathbf{7 8 0}} / \mathbf{R}_{\mathbf{7 0 0}}$ & $\mathbf{S D}$ & $\begin{array}{c}\text { Biomass } \\
\left(\mathbf{K g} / \mathbf{m}^{2}\right)\end{array}$ & $\begin{array}{c}\mathbf{S D} \\
\left(\mathbf{K g} / \mathbf{m}^{2}\right)\end{array}$ \\
\hline FW & $0.8995 \mathrm{c}$ & 0.012 & $16.0235 \mathrm{~b}$ & 2.787 & $2.999 \mathrm{a}$ & 0.292 \\
DW & $0.9022 \mathrm{~b}$ & 0.009 & $16.6098 \mathrm{a}$ & 2.281 & $2.743 \mathrm{ab}$ & 0.438 \\
MW & $0.9294 \mathrm{a}$ & 0.017 & $10.0034 \mathrm{c}$ & 3.977 & $2.497 \mathrm{~b}$ & 0.410 \\
\hline
\end{tabular}

GIS maps based on spectral reflectance index $\left(\mathbf{R}_{780} / \mathbf{R}_{740}\right)$ and spectral reflectance index $\left(\mathbf{R}_{780} / \mathbf{R}_{700}\right)$ to present the heterogeneity in vegetation of Clover biomass

The heterogeneity in vegetation of Clover biomass under different water quality of fresh, drainage and mixed water are shown in Figures 3 and 4. 
GIS tools and spectral reflectance indices of passive reflectance sensor were used to produce the GIS Maps. The data of two spectral indices $R_{780} / R_{740}$ or $R_{780} / R_{700}$ are used to drive the intervening values using the interpolation tools in ArcGIS Spatial Analyst. The two spectral indices were selected depend on the changes in curves of spectral reflectance of Clover cultivar under fresh, drainage and mixed water treatments (Fig. 3).

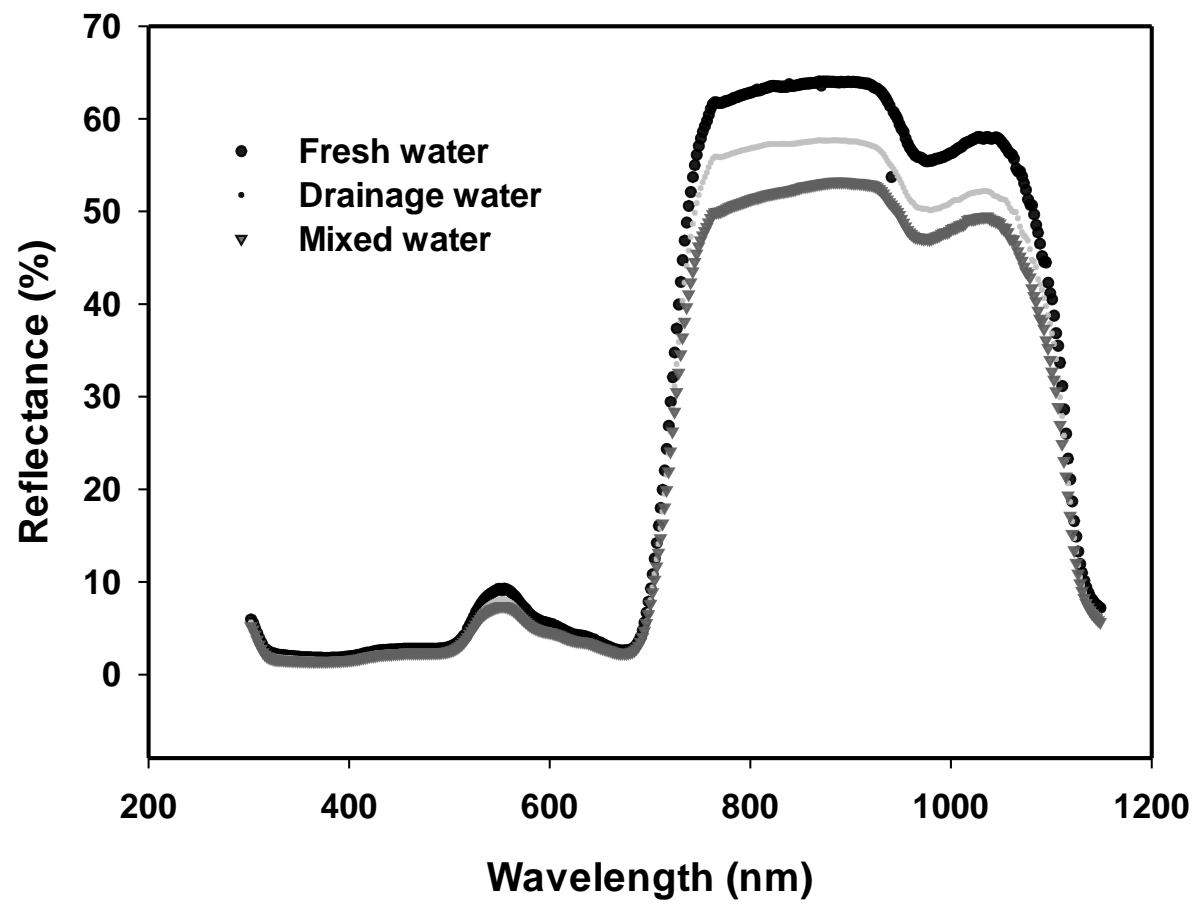

Figure 3. Spectral reflectance curves for lover under fresh, drainage and mixed water treatments

The curves shown that, the reflectance values of Clover biomass under fresh water treatment at visible and near infrared regions are higher than the reflectance values of Clover biomass under drainage and mixed water treatments. This is due to the reduction in reflectance values at visible region are more affected by relative chlorophyll or other pigments and the increasing in reflectance values at near infrared region are more affected by the amount of aerial biomass (Mistele and Schmidhalter. 2008). As well as (Haboudane et al., 2002) reported that light reflected by 
vegetation in the visible region of the spectrum is predominantly influenced by the presence of chlorophyll pigments in the leaf tissues, and these relate to the leaf nitrogen concentration. In our study the green dark of leaves apparent under mixed water than other treatments and this is due to the higher chlorophyll pigments concentrations in the leaf under mixed water than under fresh and drainage water treatments.

Inverse Distance Weighted interpolated maps of two spectral reflectance readings taken at the monitoring sites are shown in Figures 4 and 5. All geographic representation is then expressed by assigning attributes to these cells. These cells are sometimes called pixels. The colours of cells in the figure represent different values on a nominal scale which varied depend on the spectral reflectance of the plant canopy. The Inverse Distance Weighted determined cells values using a linear -weighted combination of set samples points of spectral reflectance data. The passive reflectance data provide a rapid and easy means of establishing the spatial distribution and variability of the Clover biomass. Maximum values of spectral reflectance index $\left(\mathrm{R}_{780} / \mathrm{R}_{740}\right)$ on the maps mean that the Clover biomass is low; on other hand Maximum values of spectral reflectance index $\left(\mathrm{R}_{780} / \mathrm{R}_{700}\right)$ mean that the Clover biomass is high. The heterogeneity in vegetation of Clover biomass over all the sites are likely to be the result of different parameters such as changes in soil elements, soil physical, hydraulic properties and plant density. These results are in agreement with Kiziloglu et al. (2008), who reported that untreated water treatment increased soil salinity, organic matter, exchangeable $\mathrm{Na}, \mathrm{K}, \mathrm{Ca}$, $\mathrm{Mg}$ and decreased soil $\mathrm{pH}$.

Quality of classified data was assessed through confusion matrix analysis by using independent testing data. The classified data were subsetted at administrative level to compile the district wise crops estimates. Clover biomass forecasting and estimation cover important dimension of crops statistics being of mostly qualitative nature. Two spectral indices data is main biomass predicting variable in all calibrated models. Crop phenology was mapped along with the related two spectral indices values to find out the direct relationship with Clover biomass. 


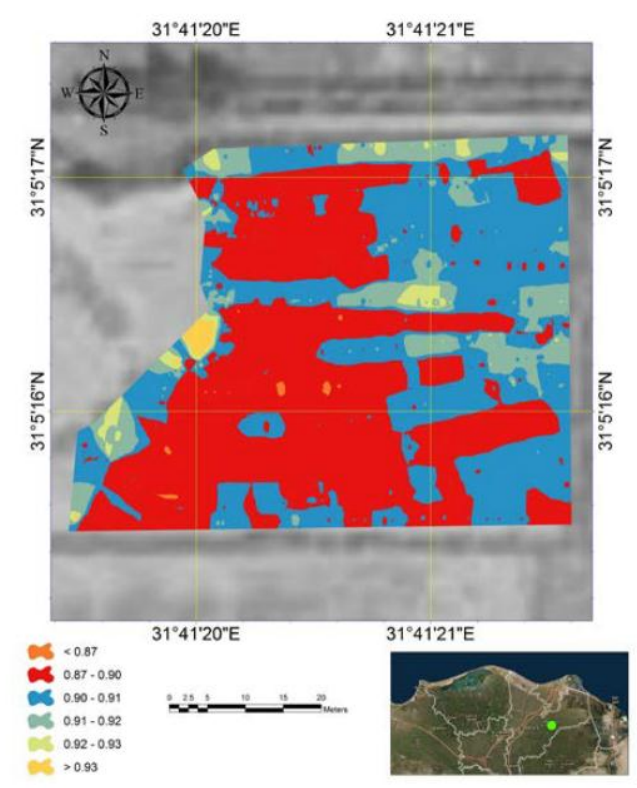

Fig. 4 a

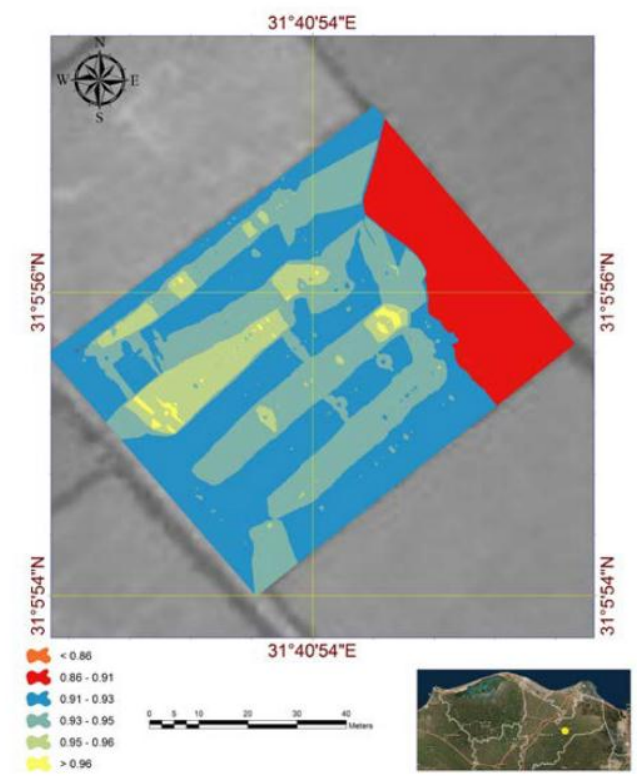

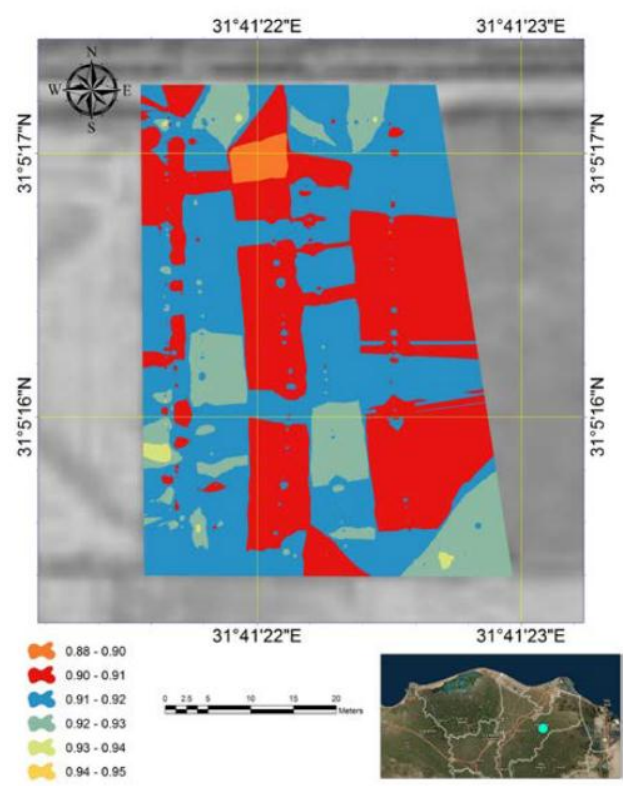

Fig. 4 b

Fig. $4 \mathrm{c}$

Figure 4. GIS maps based on spectral reflectance index $\left(\mathbf{R}_{780} / \mathbf{R}_{740}\right)$ to present the heterogeneity in Clover biomass under (a) fresh water, (b) drainage water and (c) mixed water. 


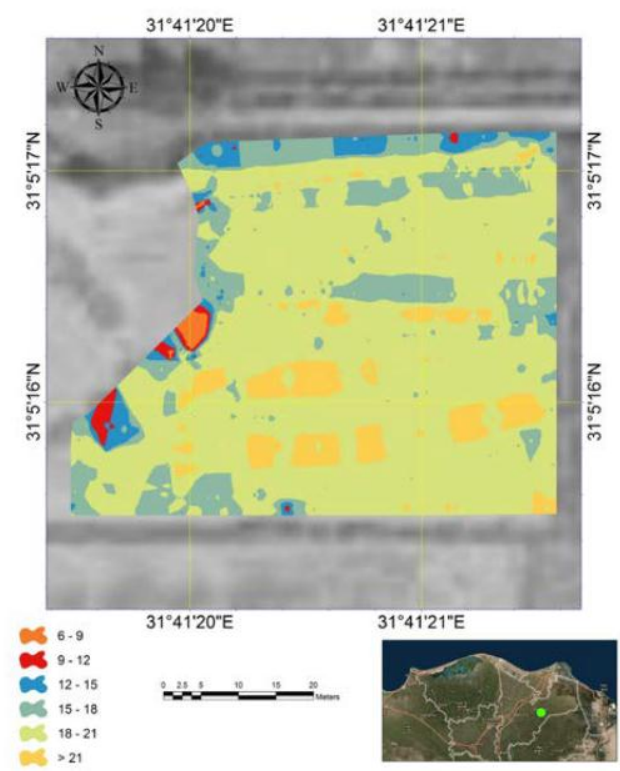

Fig. 5 a

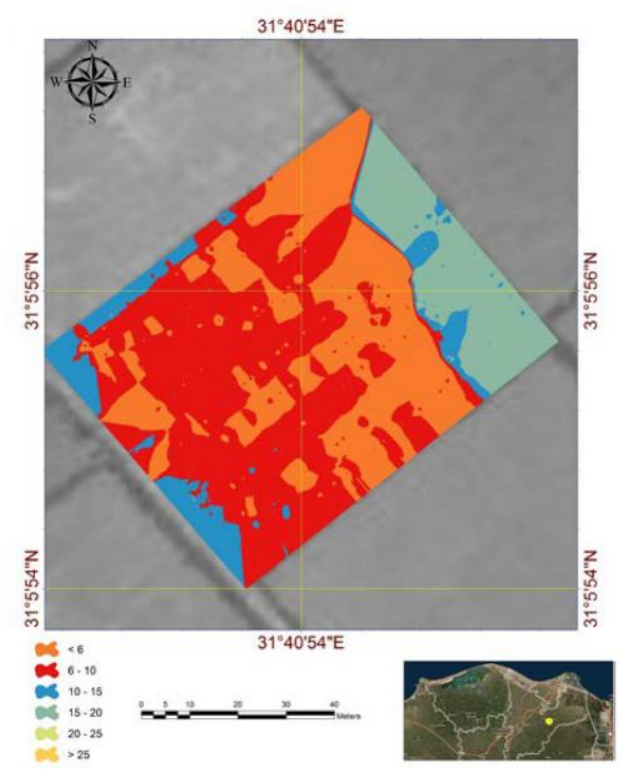

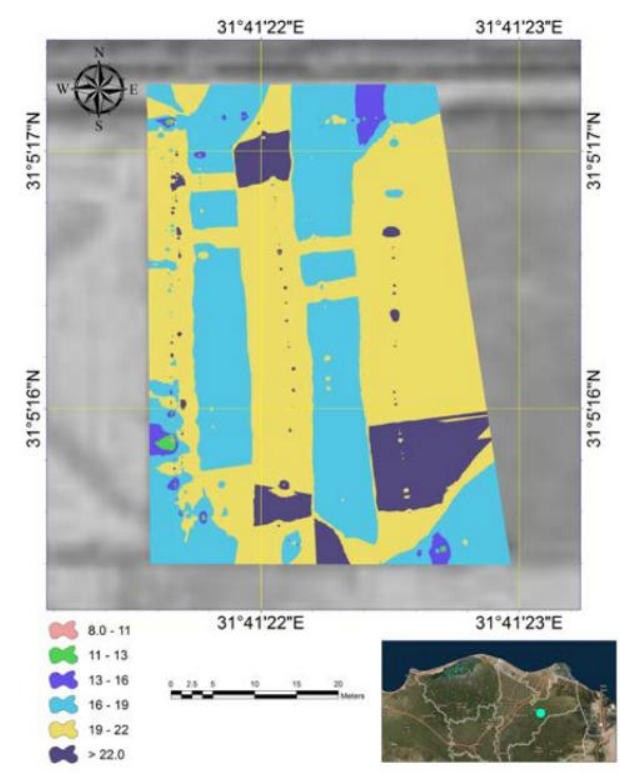

Fig. 5 b

Fig. $5 \mathrm{c}$

Figure 5. GIS maps based on spectral reflectance index $\left(\mathbf{R}_{780} / \mathbf{R}_{700}\right)$ to present the heterogeneity in Clover biomass under (a) fresh water, (b) drainage water and (c) mixed water. 
All spatial databases were developed into a model calibrating matrix. Spectral index $\left(\mathrm{R}_{780} / \mathrm{R}_{740}\right)$ and spectral index $\left(\mathrm{R}_{780} / \mathrm{R}_{700}\right)$ profile helped to differentiate Clover biomass under three water treatments (Figures $4 \& 5$ ).

\section{The relationship between two spectral indices and Clover biomass} subjected to fresh water (FW), drainage water (DW) and mixed water (MW) treatments

To test the performance of GIS maps based on two spectral indices for estimating Clover biomass under three water qualities. Ten samples of biomass for each side were cut and their values were correlated or related with two spectral reflectance indices. The relationship between spectral indices $\left(\mathrm{R}_{780} / \mathrm{R}_{740}\right)$ and spectral indices $\left(\mathrm{R}_{780} / \mathrm{R}_{700}\right)$ with Clover biomass was determined under three water treatments. Significant negative relationships were found between spectral index $\left(\mathrm{R}_{780} / \mathrm{R}_{700}\right)$ and Clover biomass. By contrast, significant positive relationships were found between spectral index $\left(R_{780} / R_{740}\right)$ and Clover biomass under fresh, drainage and mixed water treatments. Coefficients of determination were calculated as quadratic relationships between Clover biomass and two spectral indices for each water treatment. There were a more pronounced strong relationships between spectral index $\left(\mathrm{R}_{780} / \mathrm{R}_{740}\right)$ and alfa biomass and the coefficients of determination varied between $(0.92 * * *$ to $0.93 * * *)$ under three water qualities (Fig. 6). There were a more pronounced strong relationships between spectral index $\left(\mathrm{R}_{780} / \mathrm{R}_{700}\right)$ and clover biomass and the coefficients of determination varied between $\left(0.88^{* *}\right.$ to $\left.0.96^{* *}\right)$ under three water qualities (Fig. 7). As well as well relationships were found between the two spectral reflectance indices and clover biomass under combined the data of fresh water, drainage water and mixed water and the coefficients of determination varied between $(0.74 * * *$ to $0.75 * * *)$ in Fig. 8 . These results are in agreement with Aparicio et al. (2002) who found that the normalized difference vegetation index (NDVI) is associated with biomass and the leaf area index (LAI). The results demonstrated that the selected two spectral reflectance indices were apparently useful for estimating Clover biomass under three water qualities. 

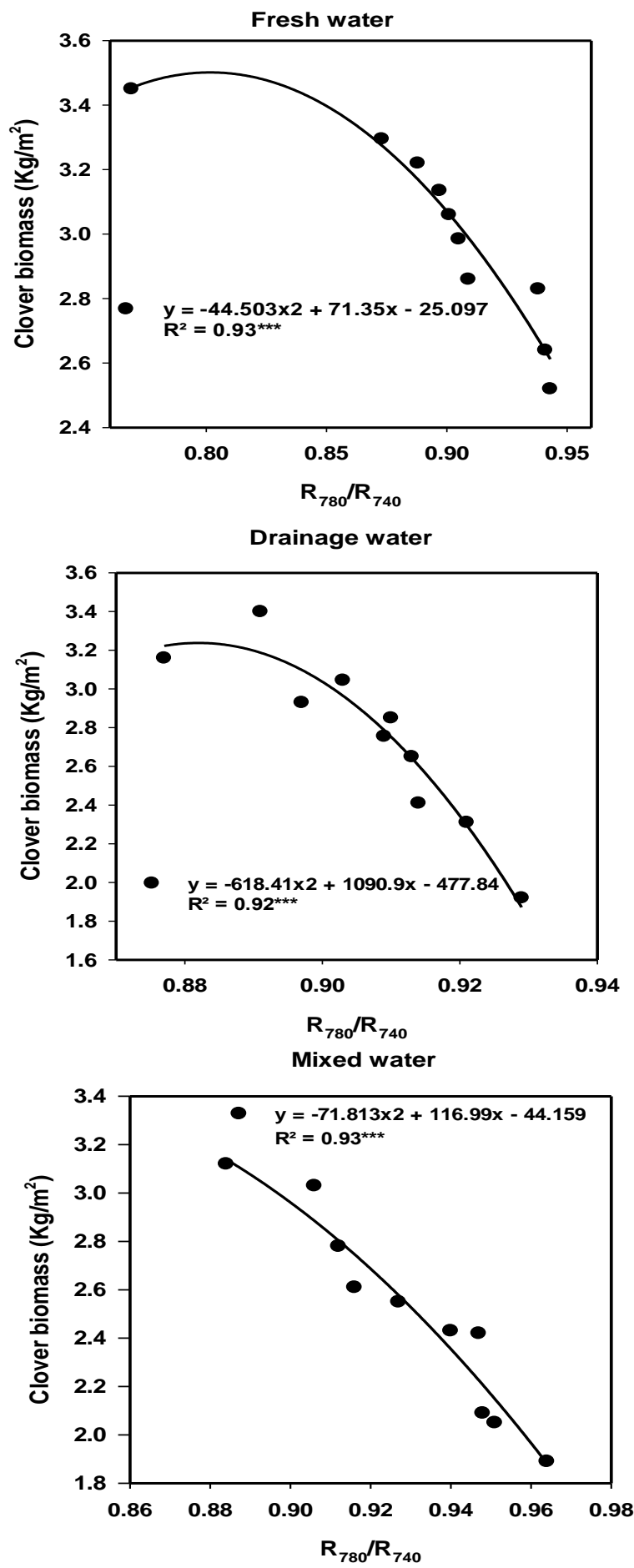

Figure 6. The relationship between spectral reflectance index $\left(\mathbf{R}_{780} / \mathbf{R}_{740}\right)$ and Clover biomass under fresh water, drainage water and mixed water. 

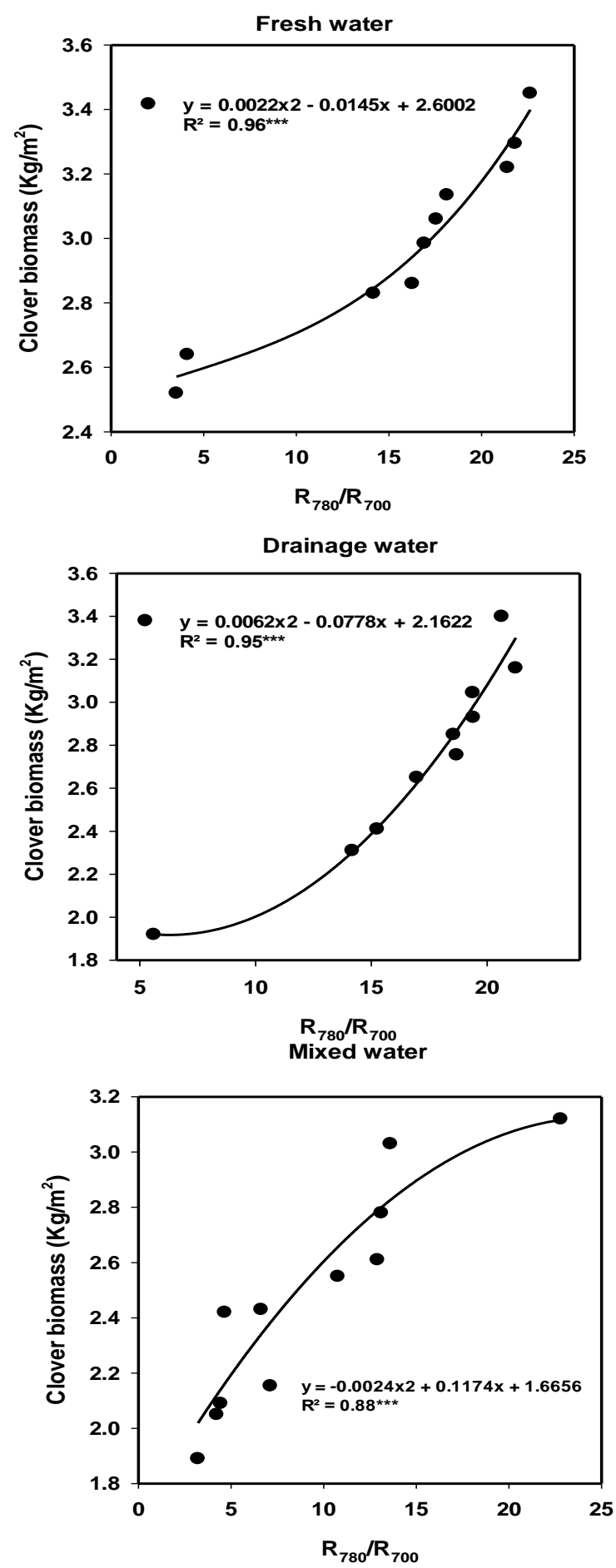

Figure 7. The relationship between spectral reflectance index $\left(\mathbf{R}_{780} / \mathbf{R}_{700}\right)$ and Clover biomass under fresh water, drainage water and mixed water. 

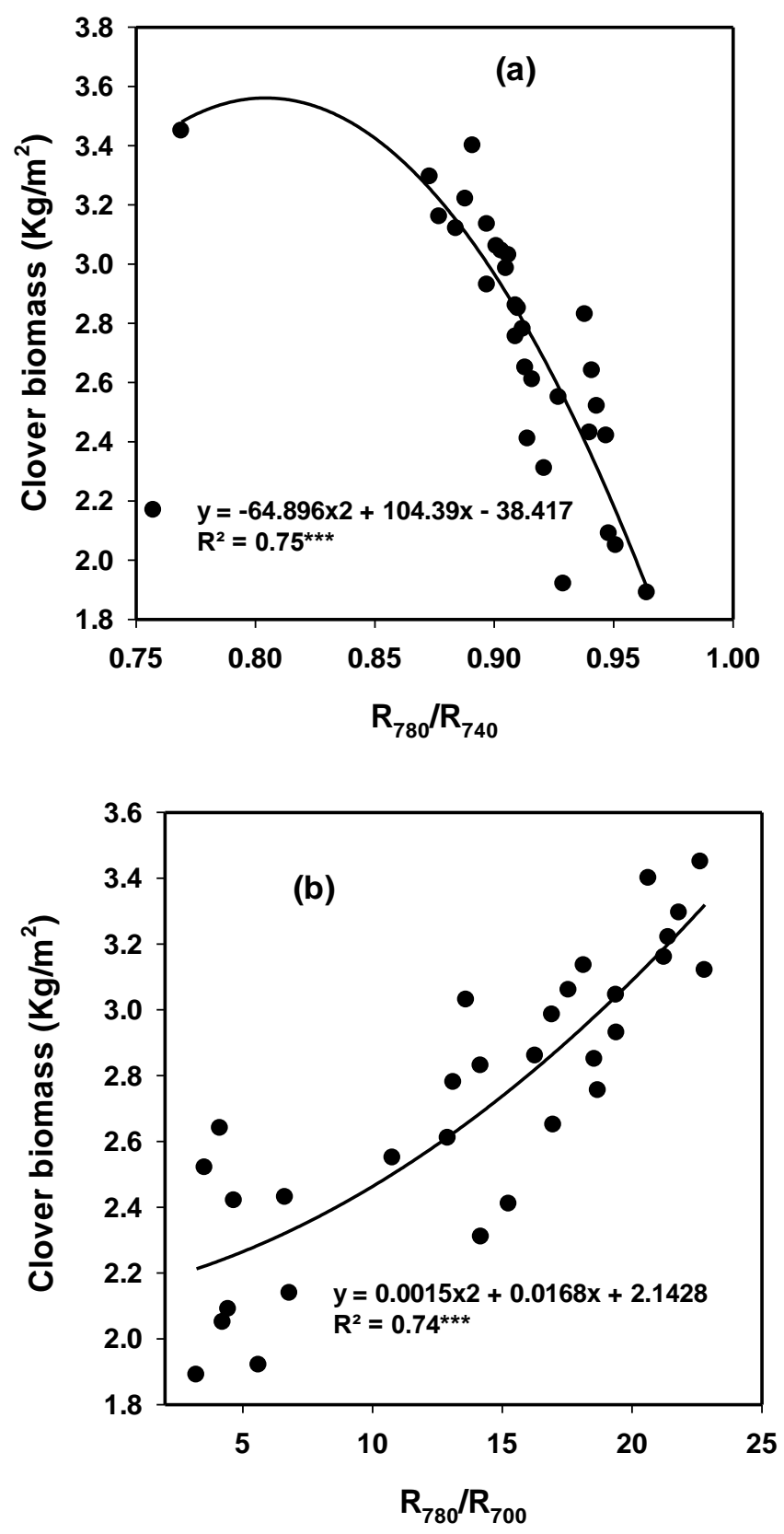

Figure 8. The relationship between (a) spectral reflectance index $\left(\mathbf{R}_{780} / \mathbf{R}_{740}\right)$ and Clover biomass under combined of fresh water, drainage water and mixed water as well as (b) spectral reflectance index $\left(\mathbf{R}_{780} / \mathbf{R}_{700}\right)$ and Clover biomass under combined of fresh water, drainage water and mixed water. 


\section{CONCLUSIONS}

The results show that the GIS maps based on two spectral indices reliably assessed the Clover biomass under three water qualities. Two models based on (i) the spectral reflectance index $\left(\mathrm{R}_{780} / \mathrm{R}_{740}\right)$ and (ii) the spectral reflectance index $\left(\mathrm{R}_{780} / \mathrm{R}_{700}\right)$ potentially improve non-invasive measurements the Clover biomass under three water qualities. The two spectral indices have good relationship with Clover biomass under combined of fresh water, drainage water and mixed water. The spectral reflectance range of near infrared and visible regions seem to be well indicator for detect Clover biomass under different water quality. Further work should also investigate the accumulative of heavy metals in water, soil and plant as well as the microbiology effect in this area of study.

\section{REFERENCES}

Allam A.E. and Negm, A.M. (2013). Agricultural drainage water quality analysis and its suitability for direct reuse in irrigation: case study: Kafr El-Sheikh governorate, Egypt", Seventeenth International Water Technology Conference, IWTC17 Istanbul, 5-7 November.

Aparicio, N., Villegas, J., Araus, L., Casadesus, L., Royo, C. (2002). Relationship between growth traits and spectral vegetation indices in durum wheat. Crop Sci. 42, 1547- 1555.

Auerswald, K., Sippel, R., Kainz, M., Demmel, M., Scheinost, S., Sinowski, W., Maidl, F. X. (1997). The crop response to soil variability in an agroecosystem. In: Auerswald, K., H. Stanjek, and J. M. Bigham (Ed.), Soil and Environment: Soil Processes from Mineral to Landscape Scale. Catena Verlag, 39-54.

Brus, D.J., Gruijter, J.J., Marsman, B.A., Visschers, R., Bregt, A.K., Breeuwsma, A., (1996). The performance of spatial interpolation methods and choropleth maps to estimate properties at points: a soil survey case study. Environmetrics. 7: 1-16

El-Hendawy, S., Al-Suhaibani, N., Salem, A., Ur Rehman, S., Schmidhalter, U. (2015). Spectral reflectance indices as a rapid 
nondestructive phenotyping tool for estimating different morphophysiological traits of contrasting spring wheat germplasms under arid conditions. Turk. J. Agric. For. 39: 572-587.

Elsayed, S., Rischbeck, P., Schmidhalter, U. (2015). Comparing the performance of active and passive reflectance sensors to assess the normalized relative canopy temperature and grain yield of droughtstressed barley cultivars. Field Crop Res. 177:148-160.

El-Shikha, D.M., Waller, P., Hunsaker, D., Clarke, T., Barnes E. (2007). Ground-based remote sensing for assessing water and nitrogen status of broccoli. Agr Water Mange. 92:183-193.

Erdle, K., Mistele, B., Schmidhalter, U. (2011). Comparison of active and passive spectral sensors in discriminating biomass parameters and nitrogen status in wheat cultivars. Field Crops Res. 124: 74-84.

Haboudane, D., Miller, J. R., Tremblay, N., Zarco-Tejada, P. J., Dextraze, L., (2002). Integrated narrow-band vegetation indices for prediction of crop chlorophyll content for application in precision agriculture. Remote Sens. Environ. 814: 16-426.

Heil, K., Schmidhalter, U. (2015).Comparison of the EM38 and EM 38MK2 electromagnetic induction-based sensors for spatial soil analysis at field scale. Comput Electron Agric. 11: 264-28.

Jurwakar, A.S. Jurwakar, A., Deshbharatar, P.B., Bal, A.S. (1991). Asian Experiences in Integrated Plant Nutrition, 178-201, RAPA. FAO, Bangkok.

Kiziloglu, F.M., Turan, M., Sahin, U., Kuslu, Y., Dursun, A., (2008). Effects of untreated and treated wastewater irrigation on some chemical properties of cauliflower (Brassica olerecea L. var. botrytis) and red cabbage (Brassica olerecea L. var. rubra) grown on calcareous soil in Turkey. Agr Water Mange. 95: 716724. 
Mistele, B., Schmidhalter, U. (2008). Spectral measurements of the total aerial $\mathrm{N}$ and biomass dry weight in maize using a quadrilateral-view optic. Field Crops Res. 106: 94-103.

Rischbeck, P., Elsayed, S., Mistele, B., Barmeier, G., Heil K., Schmidhalter U. (2016). Data fusion of spectral, thermal and canopy height parameters for improved yield prediction of drought stressed spring barley. Eur. J. Agron. 78: 44-59.

Thoren, D., Schmidhalter, U. (2009). Nitrogen status and biomass determination of oilseed rape by laser-induced chlorophyll fluorescence. Eur. J. Agron. 30: 238-242.

Yadar, R.K., Goyal, R., Sharma, R.K., Dubey, S.K., Minchas, R.S. (2002). Post irrigation impact of domestic sewage effluent on composition of soils, crops and ground water - a case study. J. Environ. Int. 28:481-486.

Woolley, J. T. (1971). Reflectance and transmittance of light by leaves. Plant Physiol. 47: 656- 662.

الملخص العربح

تحديد تأثير جودة مياة الري علي عدم التجانس في الكتلة الحيوية للبرسيم باستخدام نظم المعلومات الجغرافية و كذلك مجس الأستشعار عن بعد السلبي

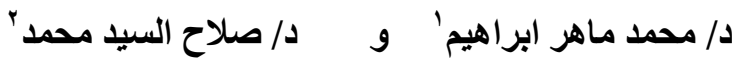

في ظل محدودية مياة الري وعدم وصول مياة نهر النيل النقية لنهايات النرع يدفع الزراع إلي الني

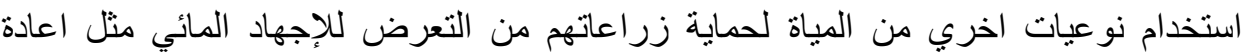

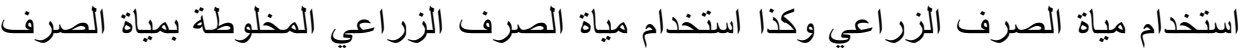

استخدام تكنولوجيا الزراعة الدقيقة بالإعتماد علي مجس الاستشعار للانعكاس الطيفي وكذلك أدوات نظم المعلومات الجغرافية يتيح سرعة في قياس عدم تجانس الإنس الكتلة الحيوية أو الكساء الخضري للمحاصيل داخل الحقل الواحد عن طريق القياسات الغير ملامسة للنبات لتحديد العو امل المختلفة. فتحديد عدم التجانس و كيفية معالجتها بالقياسات التقليدية لتغطية مساحة كبيرة من الأرض الزراعية تكون شاقة وتستغرق وقتا طويلا.

'مدرس - بقسم الهنسسة الزراعيةـ كلية الزراعة جامعة المنصورة

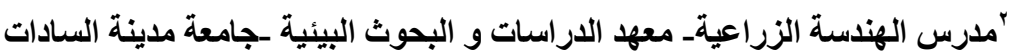


لذا في هذه الدراسة تم تحديد كفاءة استخدام خر ائط نظم العلومات الجغر افية المنتجة بالإعتماد

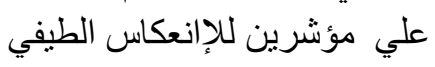

Spectral reflectance index (NIR/NIR) and spectral reflectance index في تحديد عدم التجانس في الكتلة الحيوية او الكساء الخضري تحت التأثير التر اكمي

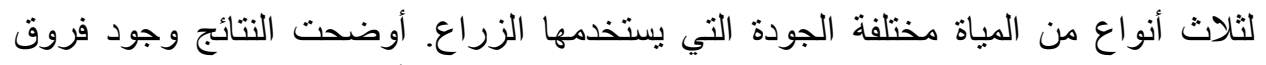
معنوية بين قيم المؤشرين الطيفيين و كذلك الكتلة الحيوية بين الأنواع الثثلاثة من المياة مختلفة

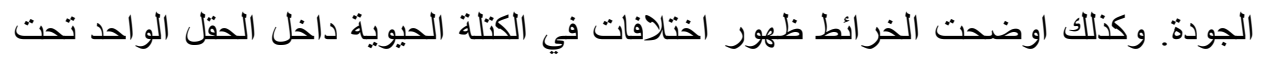
تأثير نوع واحد من جودة المياة. وكذا أوضحت النتائج أن المؤشر الأستشعاري الطيفي ذو معامل ارتباط قوي و معنوي حيث تصل (Spectral reflectance index (NIR/NIR))

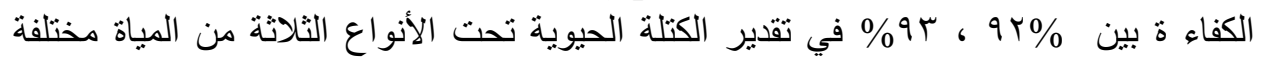

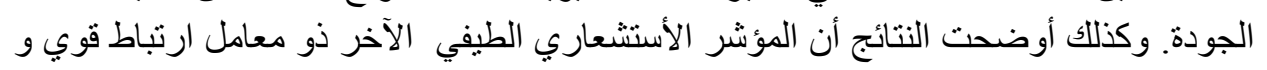

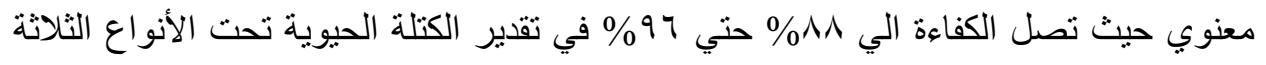
من المياة. في الخلاصة وجد ان استخدام نكنولوجيا الزراعة الدقيقة عن طريق خرائط نظم المعلومات

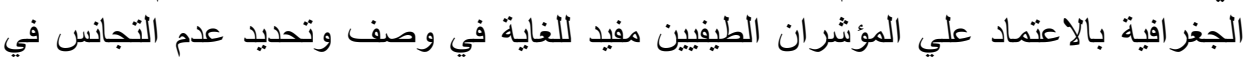

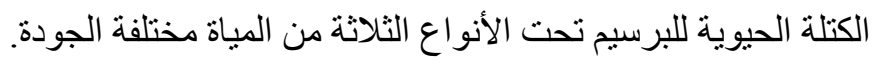

